Article

\title{
Sustainable Development and European Banks: A Non-Financial Disclosure Analysis
}

\author{
Simona Cosma $\left.{ }^{1}{ }^{(}\right)$, Andrea Venturelli ${ }^{1, *}$, Paola Schwizer ${ }^{2}$ and Vittorio Boscia ${ }^{1}$ \\ 1 Department of Economic Sciences, University of Salento, Via per Monteroni, n.7, 73100 Lecce, Italy; \\ simona.cosma@unisalento.it (S.C.); vittorio.boscia@unisalento.it (V.B.) \\ 2 Department of Economics, University of Parma, 43121 Parma, Italy; paola.schwizer@unipr.it \\ * Correspondence: andrea.venturelli@unisalento.it
}

Received: 8 July 2020; Accepted: 28 July 2020; Published: 30 July 2020

\begin{abstract}
This paper aims at contributing to the debate on the relationships between the European financial sector and sustainable development. Using a non-financial disclosure analysis of 262 European banks, the research sought, first, to investigate the "scope" of the contribution of European banks to the Sustainable Development Goals (SDGs) and, second, to explore the factors that seem to differentiate the SDGs approach among banks. The results show that country of origin, legal system, and adoption of an integrated report seem to differentiate banks in terms of contribution to the SDGs. The business model and stock exchange listing, conversely, do not seem to represent discriminatory factor in the contribution of banks toward the SDGs. The study can be useful for managers and decision makers to develop policies to support organizations in contributing to the SDGs.
\end{abstract}

Keywords: sustainable development goals; SDG reporting; 2030 agenda; European banks; non-financial disclosure

\section{Introduction}

The Sustainable Development Goals (SDGs) introduced by the 2030 Agenda represent a new challenge within the corporate strategic process and at the same time an issue that has not yet been examined in detail by literature. The 2030 Agenda is a project signed on 25 September 2015 by 193 UN Countries on the basis of which they have formally engaged in reaching 17 SDGs and 169 targets over a time period of 15 years, or rather, within 2030 (hence the project name). The 17 goals set by the 2030 Agenda are interconnected and indivisible and take into account the three dimensions of sustainable development: Economic growth, social inclusion, and environment protection. The achievement of these goals may only be completed through a joint effort of various stakeholders and a strong and effective collaboration between public and private partners [1-3] such as companies, administrations, international institutions, local authorities, scientific and academic communities, and society in general. The EU has played a determining role in defining the 2030 Global Agenda, which is consistent with the objectives of Europe.

In this path, banks are called upon to perform a leading role in virtue of their capacity to direct the conduct of companies, administrations, and families toward the priority goals. This aspect is connected to the specific activities of credit and financial intermediation, such as screening, monitoring, enforcement, and the possible consideration of ethical, social, and environmental factors in funding provision and investment activities. This important role is recognized by the European Supervisory Authorities. In particular, the European Commission promoted an action plan for financing sustainable growth (March 2018) and adopted, on 24 May 2018, the first concrete actions that assign a prominent role to EU's financial sector in fighting against climate change and in implementing the Paris agreement. The Action Plan on Financing Sustainable Growth places a particular emphasis 
on the systemic importance of the financial sector in enabling the transition to a low-carbon and climate-resilient economy.

In this perspective, the Non-Financial Reporting Directive fosters how banks and insurance companies should look at the recommended disclosures on climate change [4] from the particular perspective of their business activities, including lending, investing, insurance underwriting, and asset management activities [5].

Despite that the monitoring of progress on the path toward the SDGs carried out by several European countries is a subject of study by administrations, governmental agencies, and consulting companies [6-9] through several indicators, most of the surveys available consider the financial sector as a whole and provide a brief report of their performance compared with other sectors without focusing the attention on banks and their contributions to the SDGs [10-14].

On the basis of the commitment required from the financial sector and the role played by the banks, this paper aims at contributing to the debate on the relationships between the European financial sector and sustainable development by attempting to understand if and how European banks are advancing along the path of the strategic orientation toward the SDGs.

The contribution provided by the banks to the SDGs can be evaluated by analyzing several critical processes covering strategic planning, governance, administration, finance, and control, to come until the process of reporting [15].

By means of the reporting, banks are in fact called upon to provide an account of their contribution to sustainable development for their stakeholders through a process of accountability (rather than accounting) in line with the aim of the 2030 Agenda, so as to overcome the limits of the Millennium Development Goals Framework [16].

Starting from a consideration expressed by the World Business Council for Sustainable Development (2002), according to which "( ... ) corporate sustainability reporting indicates" public reports (published) by companies (in order) to provide internal and external stakeholders with a picture of corporate position and activities on economic, environmental and social dimensions ( ... ) in short, such reports attempt to describe the company's contribution toward sustainable development ( . . )" [17], this explorative study intends to evaluate the contribution from banks of the EU Countries to sustainable development through an analysis of the non-financial disclosure on the SDGs (hereinafter referred to as "SDG reporting").

The paper attempts to answer the following research questions:

1. Toward which SDGs is the non-financial reporting activity of European banks oriented?

2. What is the contribution of European banks to the SDGs?

3. Which contextual factors seem differentiate the contribution of European banks to the SDGs?

The 17 SDGs are considered by the United Nations to be of equal dignity and should be implemented in their own totality [18]. At the same time, each firm can freely decide which goals have priority. These priorities can be conditioned by the country, the economic sector of activities, the business model, the regulatory framework, the firm culture, the interests of the relevant stakeholders, etc. [19-21]. Although literature is developing in this regard, the recent introduction of the SDGs makes the same scarce. In particular, one of the research areas characterized by very few studies is represented by the banking sector. This research aims to fill this gap by investigating the priorities and reporting methods of the Banks belonging to 22 European countries.

The paper tries to contribute to the literature not only by carrying out a "reconnaissance" of the SDGs on which European banks declare to commit, but also evaluate the "scope" of the contribution by estimating how many, how, where, and for the benefit of whom, the SDGs are reported. A further contribution to the literature derives from the identification of the factors that seem to differentiate the SDGs approach among banks.

This paper follows a traditional structure. Section 2 provides a framework of the contribution within the reference literature. Section 3 describes a sample of the EU banks investigated. Section 4 
describes the methodology used to answer the research questions. Section 5 describes and interprets results in light of previous studies. Section 6 discusses the main implications of the evidence emerged from the survey and presents conclusions.

\section{Literary Review}

Understanding the dynamics behind the integration of the SDGs within non-financial reports represents one of the main future challenges for business and management's scholars [22]. On this point, the last years have been interested by a wide dissemination of preliminary contribution inspired by the needs to systematize the scientific knowledge on the topic [23]. Furthermore, the centrality of the topic has been underlined by policy makers and NGOs [24]. However, previous studies have highlighted the existence of complexities that negatively impact on the systematization of firms' contribution to the SDGs within a theoretical framework. In detail, a study conducted by Schaltegger [24] suggests that the interlinkage between the 17 SDGs and the difficulty to identify a direct clear connection between firms and some goals negatively impact on the development of a theoretical framework [25]. In this sense, the first five years after the launch of 2030 Agenda has been characterized by the development of studies based on prior theoretical framework used in non-financial reporting research.

\subsection{SDG Reporting and Banking Sector}

2030 Agenda explicitly calls into action the private sector [26] with the role of enabling toward the transition to a more sustainable society. Despite the proliferation of new forms of regulation on non-financial reporting, the approach toward SDG reporting is voluntary [25] and the current debate is characterized by the absence of a set of specific standards on SDG reporting. Thus, the integration of the SDGs within the non-financial reports is driven by the need to engage with stakeholders and not by an institutional pressure made by regulators. The integration of the SDGs within the non-financial statement represents a strategy used by firms to engage with stakeholders. In particular, the quick increase of the overall number of non-financial reports disclosed yearly reduces the signaling effects related to the adoption of reporting system [27]. In this sense, the integration of the SDGs represents a way to increase the accountability of the information provided by firms regarding their contribution to the society [23]. In fact, according to legitimacy theory, the disclosure of non-financial information represents an effective way to gain, maintain, and repair reputation [28]. Thus, the voluntary disclosure of information on SDGs within contexts characterized by non-financial regulation (e.g., Europe) represents a way to avoid the negative externalities caused by the adoption of tick-box approach by competitors. In detail, on the one hand, the integration of the SDGs favors the identification of firms inspired by sustainable behaviors [29]. On the other hand, the disclosure of the SDGs within a real orientation toward sustainable principles is an activity characterized by a high degree of complexity. On that point, scholars have started to discuss about a new frontier of Greenwashing called "SDG-Washing" [30].

The current scenario is characterized by shortage of studies on SDG reporting practices. In particular, as evidenced by Tsalis and colleagues [31], the last years have been interested by the development of several studies based on compound indicators used to evaluate the overall quality of SDG reporting practices. The authors underlined that some fields are not yet adequately explored. In particular, one of the research areas characterized by very few studies is represented by banking sector. The main contribution provided to the debate is represented by the paper of Avrampou et al. [32]. The paper analyzes a limited number of European banks in order to evaluate their overall degree of contribution to the SDGs. Thus, the overall knowledge on one of the main sectors involved within the policies on SDGs still remains low. In addition, the existence of relationships between financial institutions and controversial firms (e.g., tobacco, oil and gas) underlines the need to better analyze the sector in order to evaluate both managerial and policy implications [33]. 


\subsection{Literary Review on SDGs}

A first systematization attempt of SDGs studies can be found in Bebbington and Unerman [23] who, while tracing the "future research agenda", identify the following strands:

1. The use of accounting technologies for monitoring the pursuit of the SDGs, both individually and combined together [34];

2. The use of social media and big data for the collection and subsequent elaboration of relevant information for the analysis of the SDGs and the implementation of specific performance indicators;

3. The role of education toward awareness of the SDGs [35,36];

4. The importance of a synergy between the various levels of governance (local, domestic, and global) for achieving the goals (among which, in particular, are SDGs 16 and 17), the implementation of which is subordinated to the adoption of a range of instruments [34].

The most relevant studies on the SDGs and sustainable development, although exploring various subjects, are mainly focused on management [6,37], accounting, and accountability [38].

Within the literature on accounting and accountability on SDGs, it is possible to identify some strands of research:

1. Studies focused on the "narratives" of the reports, which critically investigate the use of reporting of the SDGs [39-41].

2. Thematic studies that address aspects related to the connectivity $[6,42,43]$, the integration between objectives [44], or the identification of macrothemes the most SDGs converge [45,46].

3. Comparative studies, aimed at identifying the priority SDGs in the different industrial sectors, geographical areas, and different categories of subjects called upon to support the achievement of the SDGs (private sector, public sector, academic community, etc. [47,48].

4. Empirical studies that seek to identify factors, internal and external, affecting or discriminating the SDG reporting [3].

Our paper fits into the two latter strands of the literature. In the first strand, Kourula [49] leads a wide review of the research published in international business and management journals and finds that the literature focuses on the following SDGs: Goals 1 (No poverty), 2 (Zero hunger), 7 (Affordable and Clean Energy), 8 (Decent work and economic growth), 9 (Industry, Innovation and Infrastructure), 10 (Reduced Inequality), 12 (Responsible Consumption and Production), 13 (Climate Action), and 17 (Partnerships to achieve the Goal). Salvia et al., 2019, through interviews with 266 experts (academics, researchers) from North America, Latin America, Africa, Asia, Europe, and Oceania, identifies the topics most frequently researched in the different Countries and explains them through connection with local problems. In particular, the most popular topics in Europe concern SDGs 4, 11, 12, 13, i.e., education, sustainable communities and cities, consumption and responsible production, and climate action. The most researched goal is represented by «Climate action».

Ranängen et al. [50] show that two Swedish municipalities have introduced several aspects of sustainability in their governance, especially in terms of society, human rights, and the environment. By using materiality analysis, the authors highlight that the use of fresh water (SDGs 6), the action for the climate (SDG 13), and biodiversity (SDGs 14,15) seem to be the most important SDGs.

As for the private sector studies, Van Zanten and Van Tulder [19] show that multinational European companies are committed toward a largest number of SDGs than North American multinationals and that multinationals in industrial sectors that have negative externalities (agriculture, alcohol, tobacco, chemicals, mines, etc.) mainly pursue the SDGs that can help "avoid damage" rather than help "do good". The most pursued goals are, in descending order, SDG 16 (Strong institutions for the peace and justice), 5 (Gender equality), 8 (Decent work and economic growth), and 12 (Consumption and responsible production). Objective 13 (climate action) is in an intermediate position (eighth) among the priority themes. 
Ike et al. [20] highlight that Japanese multinationals engage as a priority with SDGs 4 (Education), 8 (Decent work and economic growth), 9 (Industry, Innovation and Infrastructure), 11 (Sustainable Cities and Communities), and 12 (Responsible Consumption and Production).

In line with the above studies, mention should be made of the results of some surveys conducted, at the international level, by non-governmental bodies and consulting companies.

PWC [13], for instance, provides a survey on the state of SDG reporting by taking into account corporate reports issued by 729 multinational enterprises operating in 21 Countries and in 6 macro-sectors, including the financial services. The findings suggest that companies providing financial services give priority to the SDGs in line with the existing business strategies, namely goals $13,8,4,11$, and 3 .

An analysis conducted by the UN Global Compact [8] shows, conversely, that SDGs 8, 3, 5, and 4 are the goals selected by most companies.

E\&Y [51] differs from the previous reports as it makes a comprehensive analysis of the contribution provided by the financial sector to the SDGs by identifying the strategic relevance of goals 5, 8, 10, 13, and 16.

KPMG [14] provides a global overview of the state of non-financial reporting (company samples N100 and G250) and underlines the trend of SDG reporting, which quite clearly reveals that the sector of financial services gives priority to goals 13, 8, 4, 5, 11, and 13 .

One year later, KPMG itself [12] published a report that shows that only $40 \%$ of the biggest companies in the world include in their reports explicit references to the goals of sustainable development. In the sector of financial services, the rate is $37 \%$ as opposed to a peak of $58 \%$ for utilities and $28 \%$ for oil and gas.

In addition, OXFAM [52], a non-governmental organization operating in over 90 countries worldwide, investigates the content of non-financial disclosures (on the SDGs) included in the final balance sheets of 76 larger companies. From this analysis, five serious defaults emerge lack of a coherent approach to prioritize and implement the SDGs; the poor impact of the SDGs on sustainability strategies and related action plans; reduced link between policy and risk in terms of human rights and the SDGs; fragmentary and at times incoherent SDG reporting.

This report does not provide, however, specific references to the financial sector. References, conversely, can be found in some research papers conducted on the first non-financial statements (2017) (hereinafter the "DNF") of the Italian EIP:

1. Deloitte-SDA Bocconi [10], a report showing that 21\% of EIP (198 DNF published within 15 July 2018) - within the scope of the Legislative Decree 254/16 - provides SDG reporting mainly on goals 1,3 , and 11 .

2. GBS [15], a research showing that $17 \%$ of EIP (202 DNF published within 31 August 2018) provides SDG reporting. Banks, in particular, in addition to presenting a good level of SDG reporting compared with other sectors, provide quantitatively reliable and more relevant information with regard to goal 8 and higher-quality information as for goals 3, 6, 7, and 14 [15].

The above reports, except for the last one, investigate the macro-sector of financial services that include banks, insurance companies, and financial institutions. The same applies to scientific production, in the context of which only few studies have focused on the banking sector.

Among these, a recent study by Avrampou [32] proposes a method for analyzing the contribution from the banking sector to the SDGs on the basis of corporate sustainability disclosures in a sample of five large European banks. The proposed scoring system evaluates the contribution and completeness of non-financial disclosures concerning the SDGs according to the capacity of a report to provide detailed information on GRI indicators and business topics linked to the SDGs. Authors conclude that disclosures are incomplete and that the best-reported SDGs are goals 4, 8, and 16.

The present paper also refers to the last strand of literature concerning the contingency factors affecting or differentiating the implementation of sustainable development goals and of SDG reporting $[47,53,54]$. 
Among the internal (organizational) factors impacting on SDG reporting, Rosati and Faria [3] identify the greater dimension of companies, higher levels of tangible assets, a stronger commitment to the sustainability framework, external assurance, and boards characterized by a significant female presence and a lower average age. These results do not explicitly take into account the financial sector, probably included in the category "Others".

Other studies investigate the influence of internal factors and confirm the importance of sustainability reporting in promoting CSR progress [55]. Therefore, SDG reporting acts as a driver for the implementation of sustainability-oriented investments and strategies [56].

Among the external factors able to encourage due attention to the SDGs, Biermann et al. [57] underline the rate of commitment toward the SDGs and turn them into domestic goals.

Rosati and Faria [47], through the investigation of 2413 sustainability reports in six institutional systems and in 90 countries, conclude that companies are more likely to report on the SDGs in presence of external and contextual variables such as sociocultural system, educational system, and labor market, propensity of policymakers toward social responsibility, climate change vulnerability, and the presence of a variable set of instruments for protecting employment and bank-centered economies.

Starting from an analysis conducted on both strands of studies, this paper wants to contribute to the extant literature by investigating the SDG reporting in the EU banking sector, by examining 262 banks operating within the EU. This is a context involved in the transposition of the EU Directive 2014/95 on the non-financial disclosure, starting from which a new trend on SDG reporting is becoming consolidated [58]. In contrast to the other studies, this investigation is not exclusively focused on banks compliant with the GRI framework with regard to sustainability reporting, as this could lead to a misinterpretation of the findings [37]. Furthermore, the results of this study refer not only to an evaluation of the 17 goals included in non-financial disclosures issued by EU Countries' banks, but also to an investigation of some internal and external factors characterizing the levels of voluntary disclosure.

\section{The Sample}

BankFocus is the reference database. The sampling basis involves all the banks of EU Member States complying with Directive 2014/95/EU on non-financial disclosure. The Directive, as well known, requires all EIP companies (bodies of public interest) to provide a non-financial statement (in Italy DNF), including environmental, social, and personnel-related information, as well as data concerning respect of human rights and fight against active and passive corruption to the extent necessary for evaluating a company's performance, results, situation, and impact of activities [59].

In Italy, the disclosure obligation was introduced in balance sheets from 31 December 2017. Each European state has, however, implemented the Directive in a different manner.

The sample has been defined by taking into account the document: "Member State Implementation of Directive 2014/95/EU-A comprehensive overview of how Member States are implementing the EU Directive on Non-financial and Diversity Information" [60] reporting, for each EU Country, their specific legislative framework for the implementation of Directive 2014/95/EU, and field of application. Listed and non-listed companies of each EU Country falling within the scope of this directive have been selected. The choice to use the criterion of application of the EU Directive 2014/95 for the selection of the sample derives from the consideration that the law in question may have constituted a factor that gave impetus to the reporting of information relating to non-financial aspects and, presumably, to issues related to the 17 sustainable development goals.

Originally, the overall sample included 301 banks. The banks that did not publish a non-financial disclosure in English, as required from the Directive, have been excluded from the sample. The resulting final sample is composed of 262 banks, of which only 89 are listed and the other 173 are non-listed. The $53 \%$ of the sample (i.e., more than half of the sample) is represented by commercial banks (see Figure 1). 


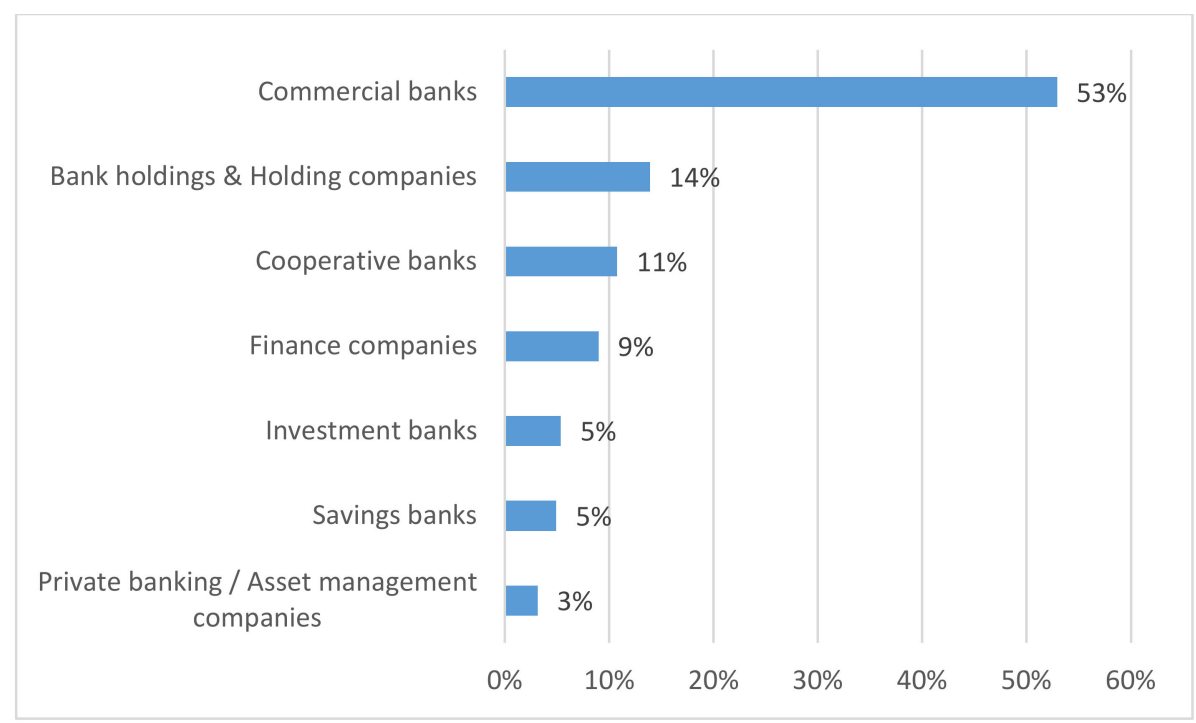

Figure 1. Composition of the sample per bank model.

From the original sample of 262 banks, it was found that $85 \%$ (223) of banks' non-financial statements concern the SDGs (see Figure 2), therefore the data used in this study refer to 223 banks belonging to 22 countries.

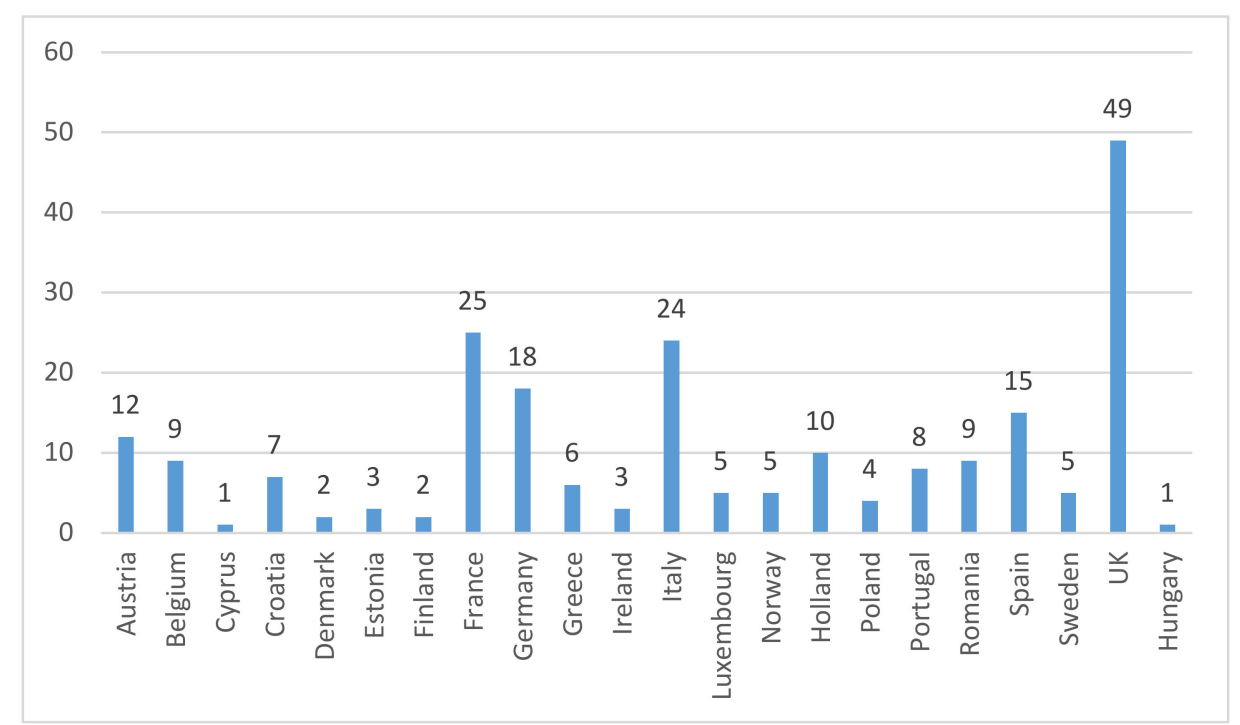

Figure 2. Number of banks reporting non-financial information concerning the Sustainable Development Goals (SDGs) by country.

\section{Methodology}

The methodology used is based on the interpretation of any possible quantitative and qualitative content (inspired by the 17 goals) included in "non-financial statements" and "consolidated non-financial statements" and referred to the 2017 accounting period of the banks selected (see Directive 2014/95/EU, articles 19a) and 29a) with mention to the document stating that EIP companies are bound to report non-financial statements as required by the Directive itself).

The subject of the investigation is the non-financial disclosure within the annual report (namely management report) or in stand-alone documents, integrated reports, and other reports. The manual content analysis (content interpretation) has been used to analyze statements without using specific software. The choice not to use a content analysis software (such as, for example, Wordstat 7 , 
Nvivo, TLab) derives from the fact that a lot of information regarding the SDGs is associated with the use of 17 icons that cannot always be processed by these tools.

The content analysis has been conducted manually by a single researcher after a preliminary assessment conducted by the entire research team. The analysis has been conducted by a single researcher in order to avoid the risks of inter-coder reliability [61]. Furthermore, we have adopted a visual content analysis conducted without the use of software due to the absence of a widely adopted SDGs' taxonomy. Thus, the adoption of a thematic or linguistic approach has been limited by the presence of picture and graphs. Finally, the coding activity has been validated by the entire research team in order to assess the reliability of the research.

More specifically, with regard to content research and analysis, the study has not only investigated the reports of banks that adopted an explicit approach to SDG reporting by using the official definitions of the 17 goals in the SDG Compass site (source: https://sdgcompass.org/sdgs/), but also the reports of banks that chose to adopt an implicit approach and used semantic expressions similar to those provided by the 17 goals. In this last case, the study has investigated, within above-mentioned analyzed reports, the topics specified in the document "Linking the SDGs and GRI" [62] and associated with the 17 goals. This document currently represents the only methodological reference for combining sustainability disclosure with the SDGs.

Within the methodological approach, it should be mentioned that for each European bank, in addition to profiling information, such as country, legal system, business model, and stock exchange listing, other more specific data on the following topics have been investigated: Number of SGDs reported, type of report section in which the SDGs are communicated, level of detail provided by disclosures with regard to the SDGs, type of report, and reference stakeholders.

The six report sections in which specific SDGs are detected are CEO letter, materiality analysis, business model, strategic plan, stakeholder engagement, and the SDGs-GRI correlation table. With regard to the level of detail concerning the SDGs, the 5-level rating scale (1-generic/narrative, 2-narrative with details, 3-quantitative only, 4-quantitative/narrative, 5-quantitative/narrative/ comparative) provided by the coding system in some studies $[63,64]$ has been traced back to 2 levels, generic (generic/narrative) and detailed (quantitative/narrative/comparative) [64].

The type of report corresponds to the different choices operated by banks in reporting the content of non-financial information with regard to the SDGs: The annual report (otherwise defined "combined reports") or voluntary reports, such as sustainability reports and integrated reports.

The reference stakeholders taken into account for the purpose of the analysis are those explicitly mentioned as recipients of the SDGs, namely clients, suppliers, employees, financing institutions, shareholders, institutions, communities, and the environment.

According to previous theoretical studies on non-financial reporting quality $[65,66]$, we have developed a compound index in order to evaluate the contribution provided by banks to the SDGs of European banks. The choice to adopt a compound index has been driven by the opportunity to approximate the overall degree of orientation toward the SDGs through a synthetic indicator. In addition, we have based our indicator on the sum of different items in order to avoid the risk of unreliability caused by the complexity of the topic [14]. The index (named Score) takes into account the following factors:

1. Number of reported SDGs (a proxy for social, economic, and environmental breadth of the contribution in terms of sustainable development (although this evaluation complies with a level of discretion, it should be noted that the proxy examined is consistent with the content of the 2030 Agenda, which suggests not only to the subscribers of the agreement, but also to the economic operators involved to commit to as many SDGs as possible, by measuring and monitoring the contributions provided).

2. Level of detail in statements (proxy for the commitment and attention paid to the SDGs by banks); for each bank, a score of 0.5 was assigned to generic disclosure and the value 1 to detailed information. The choice of 0.5 instead of 0 (in analogy with what was done previously for the 
other components of the score) is justified with a purely computational purpose: The score derives from the product of the 4 components considered, one of which is the level of detail of disclosure. In the case of generic disclosure for a bank, assigning the value 0 to it, the score would have been improperly equal to 0 regardless of the value of the other components.

3. Number of sections in which the SDGs appear (proxy for the degree of integration of the information concerning the SDGs and attention paid to the SDGs). Six sections were considered for each bank (the letter from the CEO, the materiality analysis, the business model, the strategic plan, stakeholder engagement, and the correlation table SDG-GRI) and, to each of them, a value of 0 was assigned in case of absence and a value of 1 in case of presence of SDGs disclosure.

4. Number of stakeholders (proxy for the level of attention to the demands expressed by the stakeholders involved). For each bank, 8 stakeholders were considered (customers, suppliers, employees, lenders, shareholders, institutions, communities, and the environment) assigning to each of them a value of 0 in case of absence or 1 in case of presence in the disclosure.

From an analytical perspective, these points can be transformed into a formula (for each bank):

$$
\begin{aligned}
& \text { SCORE }_{i}=\sum_{j=1}^{17} \frac{S D G s_{j}}{17} * \beta * \sum_{z=1}^{6} \frac{\text { SECTIONS }_{z}}{6} * \sum_{k=1}^{8} \frac{\text { STAKEHOLDERS }}{k} * 100 \\
& i=1, \ldots 223 ; \beta \in[0,5 ; 1]
\end{aligned}
$$

In detail, the dependent variable SCORE $E_{i}$ indicates the "scope" of contribution toward the 17 goals for a specific bank.

$\sum_{j=1}^{17} \frac{S D G s_{j}}{17}$ indicates the total number of goals reported by a specific bank, with $j=1, \ldots, 17$. The variable examined can assume, respectively, a minimum value of $1 / 17$ and a maximum of 1 ;

$\beta \in[0,5 ; 1]$ indicates the level of detail assumed by a bank for reporting on the goals. The variable can assume the value 0.5 in presence of generic disclosures or value 1 in case of detailed disclosures;

$\sum_{z=1}^{6} \frac{\text { SECTIONS }}{6}$ indicates the total number of sections with the reported SDGs, to which a bank declared its commitment. The variable can range from a minimum of $1 / 6$ to a maximum of 1 ;

$\sum_{k=1}^{8} \frac{S T A K E H O L D E R S_{k}}{8}$ indicates the total number of stakeholders mentioned by each bank and associated with the reported SDGs; the variable can range from a minimum of $1 / 8$ to a maximum of 1 , with $k=1, \ldots, 8$.

As a consequence, the contribution provided by a bank to the SDGs depends directly on the value assumed by the variables composing the index. In particular, a comprehensive contribution in terms of SDGs is determined by (1) a higher number of reported SDGs; (2) a greater level of disclosure detail; (3) a disclosure encompassing more sections and addressed to a higher number of stakeholders. The index ranges from a minimum of 0.06 to a maximum of 100 .

Finally, according to past studies on accounting and accountability $[67,68]$, we have adopted a research approach based on nonparametric test to identify the factors that differentiate the contribution of the banks to SDGs.

\section{Results and Discussion}

After conducting content analysis, this study attempted to analyze priority SDGs, the total scores, and some factors differentiating such scores.

\subsection{Priority SDGs for European Banks}

Figure 3 shows results that are consistent with the findings of other international surveys in the sector of financial services [12,13] or in the banking sector [15]. The priority goals set by banks, and thus more referred to in reports, are SDG 8 concerning the quality job and economic growth 
( $91 \%$ of banks), SDG 13 on climate change ( $81 \%$ of banks), and SDG 4 linked to quality education (76\%). In particular, the figure related to goal 13 confirms the banking sector's strategic focus on the fight against climate change, which seems to anticipate the trend set by the European Commission in 2018 on sustainable development.

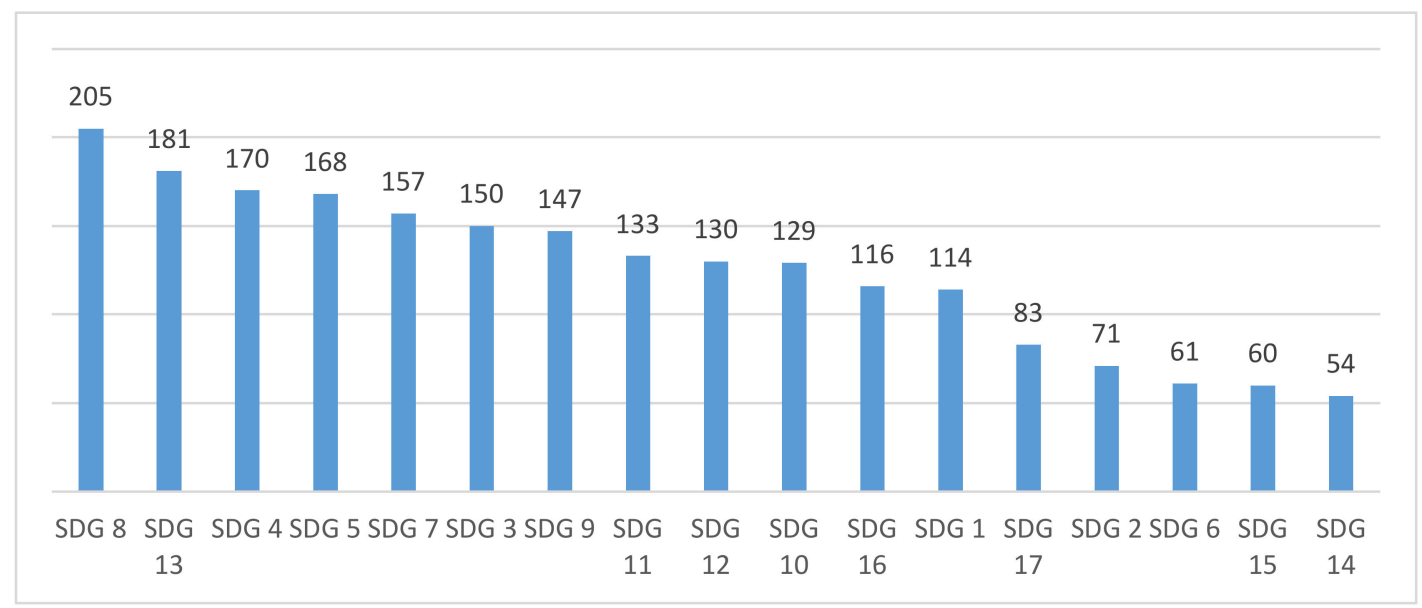

Figure 3. The most reported SDGs.

The figures on goals 14 (aquatic flora and fauna), 15 (terrestrial flora and fauna), and 6 (clean and accessible water) confirm that these are not strategic goals for the banks [32].

The results of this analysis show, therefore, a framework that is not properly consistent with the latest Eurostat Report on the 17 goals, stating that EU Countries provide a significant contribution in terms of SDG 3 (good health and wellbeing), SDG 4 (quality education), SDG 11 (sustainable cities and communities), and SDG 7 (clean energy) [69]. This result confirms, to a certain extent, a lack of strategic alignment between the European Union and its banking system.

By referring to the 22 countries, the SDGs receiving more attention from almost all countries are three, namely goal 8 (work and growth) that is the most reported in 20 countries, followed by goal 4 (education) that is the most reported in 9 countries, and 13 (climate change) in 8 countries. The least reported SDGs are two, namely goal 14 (marine life) that is the least reported in 16 countries, followed by goal 15 (biodiversity), which is the least reported in 10 countries. In some cases, the geographical position has an impact on the choice to report on some SDGs rather than others (see Holland as for SDG 6 concerning water sustainable management or Austria and Belgium as for SDG 14 on aquatic flora and fauna).

By referring to the business model, SDGs 13 (sometimes 7) and 8, respectively linked to environmental/climate topics and issues concerning economic growth and decent work, are considered priority goals (see Table 1).

Table 1. The most and least reported SDGs for business model.

\begin{tabular}{ccc}
\hline Business Model & Most Reported SDGs & Least Reported SDGs \\
\hline Bank holdings \& Holding companies & SDG 8 & SDG 14 \\
\hline Commercial banks & SDG 8 & SDG 14 \\
\hline Cooperative banks & SDG 16 & SDG 17 \\
\hline Finance companies & SDG 13 & SDG 14, SDG 15 \\
\hline Investment banks & SDG 7 & SDG 6 \\
\hline $\begin{array}{c}\text { Private banking/Asset management } \\
\text { companies }\end{array}$ & SDG 13, 7 & SDG 14, 15, 16, 17 \\
\hline Savings banks & SDG 8, 13 & SDG 6
\end{tabular}


An exception to the above is given by cooperative banks, which give priority to SDG 16 concerning issues such as peace, justice, and solid institutional structures. In fact, the main target of these banks is to protect community interests for the territory's development. Also, investment banks stand out from the other types since their priority regard goals such as ensuring access to affordable, reliable, sustainable, and modern energy for all (goal 7).

The analysis show that there the SDG preferences are similar between listed and non-listed companies. SDG 8 (economic growth and decent work), SDG 13 (fight against climate change), SDG 4 (quality education) are priority goals in bank reporting. Furthermore, the least reported goals (SDG 14, SDG 15, SDG 6) remain unchanged in the comparison between listed and non-listed banks.

An analysis of the disclosures of banks shows that more than only a small percentage of EU banks (23\%) adopt an approach focused on specific SDGs and give priority to a number of goals ranging from 1 to 5 . Half of the sample (50\% of banks) adopts a wide orientation toward the SDGs, by reporting on more than 8 SDGs. A quarter of the banks report almost/over 13 goals and the $11 \%$ address the totality of goals.

The average number of SDGs reported by banks in the different countries is highlighted in the Table 2. The Nordic countries seem adopt an approach focused on specific SDGs.

Table 2. Average number of SDGs for bank by country.

\begin{tabular}{|c|c|}
\hline EU Country & Average Number of SDGs for Bank by Country \\
\hline Denmark & 4 \\
\hline Finland & 6 \\
\hline Norway & 7 \\
\hline Cyprus & 7 \\
\hline Ireland & 7 \\
\hline Sweden & 7 \\
\hline Greece & 8 \\
\hline Belgium & 8 \\
\hline Luxembourg & 8 \\
\hline Italy & 8 \\
\hline Portugal & 9 \\
\hline Germany & 9 \\
\hline Spain & 10 \\
\hline Estonia & 10 \\
\hline UK & 10 \\
\hline Romania & 10 \\
\hline Holland & 10 \\
\hline Hungary & 11 \\
\hline Croatia & 11 \\
\hline Austria & 11 \\
\hline France & 12 \\
\hline Poland & 13 \\
\hline
\end{tabular}

\subsection{The Contribution of European Banks to the SDGs}

The contribution to the SDGs from EU banks is briefly detected through the above-described score. 
Remembering that the score can assume an average value between 0.06 and 100, the contribution from European banks appears to be limited (6.8). The median is slightly under the average, with $50 \%$ of banks not exceeding the score of 4.4. The maximum value of the score is 43.75 and it shows the existence of wide improving margins along the path of orientation and reporting toward the SDGs.

The most significant contribution, in terms of the SDGs, is shown by one commercial bank listed France. This level of the score is due to the fact that, in addition to reporting on all 17 goals, the bank publishes a detailed non-financial disclosure in three sections of her report and in the overall interest of seven types of stakeholders.

Conversely, the bank with a minimum score is a German cooperative bank, and two English banks (an investment bank and a private bank). All of them are brought together by the fact that they are non-listed companies communicating general information and taking into account 1 or 2 SDGs only in one section of their reports. The number of stakeholders is also quite limited and ranges from 2 to 4 types.

Referring to the business model, Table 3 shows a higher average score for finance companies and savings banks, however the high standard deviation value indicates different situations within the same business model. Private banking/asset management companies and investment banks result the categories that support less the SDGs.

Table 3. Statistical values linked to the score of the bank business model.

\begin{tabular}{ccccc}
\hline Business Model & Mean of Score & Dev Standard of Score & Max Score & Min Score \\
\hline $\begin{array}{c}\text { Bank holdings \& Holding } \\
\text { companies }\end{array}$ & 5.0 & 4.4 & 14.7 & 0.5 \\
\hline Commercial banks & 7.2 & 7.9 & 43.8 & 0.5 \\
\hline Cooperative banks & 7.4 & 5.4 & 14.7 & 0.2 \\
\hline Finance companies & 8.8 & 7.7 & 21.9 & 1.1 \\
\hline Investment banks & 4.9 & 3.9 & 10.3 & 0.2 \\
\hline $\begin{array}{c}\text { Private banking/Asset } \\
\text { management companies }\end{array}$ & 2.5 & 1.9 & 5.9 & 0.2 \\
\hline Savings banks & 8.3 & 6.1 & 20.2 & 1.5 \\
\hline
\end{tabular}

With reference to the country, the highest average values of the score are found in three countries: Estonia, Croatia, and Poland. This quite surprising result confirms an increasing interest of emerging countries toward the goals of sustainable development. However, a high standard deviation in these countries confirms a different level of contribution between banks of the same country.

Likewise, by examining the statistical data, while comparing listed and non-listed banks (see Table 4), both of them have approximately the same values for the average values, volatility, highest, and lowest score. The average distance of each score for both of them is distant from the average score of 7 points.

Table 4. Statistical values linked to the score of the listed and non-listed banks.

\begin{tabular}{ccccc}
\hline Stock Exchange Listing & Mean of Score & Dev Standard of Score & Max Score & Min Score \\
\hline Not listed & 7.1 & 6.9 & 43.8 & 0.2 \\
\hline Listed & 6.4 & 7.0 & 43.8 & 0.4 \\
\hline
\end{tabular}

To conclude, Table 5 shows an interesting result, namely that banks providing integrated reports give a slightly higher contribution in terms of average values than banks providing different types of report (combined or sustainability reports). Strong volatility can be found in banks that do not provide integrated reports, against a certain homogeneity in those which do so. This result could be partly 
explained by the fact that the IIRC has widely publicized the SDGs and the way in which "integrated thinking" can contribute to more effective pursuit of these goals [56].

Table 5. Statistical values linked to the score of the banks using integrated reports or not.

\begin{tabular}{ccccc}
\hline Integrated Reporting & Mean of Score & Dev Standard of Score & Max Score & Min Score \\
\hline No itegrated report & 6.7 & 7.1 & 43.8 & 0.2 \\
\hline Integrated report & 8.4 & 5.5 & 20.6 & 3.7 \\
\hline
\end{tabular}

\subsection{Factors Differentiating the Contribution of Banks to the SDGs}

In light of previous results, to better investigate if and which factors among those examined in the sample differentiate a large or narrow contribution of banks to the SDGs, we consider the following factors: Country, legal system, business model, bank listing, and use of integrated report, and implement two non-parametric tests on independent samples by using the IBM software SPSS Statistic. Non-parametric tests have been chosen due to a lack of knowledge of data distribution. The tests used are the U Mann-Whitney test (for two samples) and the Kruskal-Wallis test (for k samples with $\mathrm{k}>2$ ) that compare the distribution across groups (null hypothesis: The distribution of score is the same across categories).

Table 6 below shows the results with regard to each factor (grouping variable) and the calculated score as the dependent variable for each test.

Table 6. Non-parametric test with several grouping variables.

\begin{tabular}{ccc}
\hline Grouping Variable & Test & Sig. \\
\hline Country & Independent samples Kruskal-Wallis Test & $0.037^{* *}$ \\
\hline Legal system & Independent samples Mann Whitney U Test & $0.007^{* * *}$ \\
\hline Business model & Indipendent samples Kruskal-Wallis Test & 0.137 \\
\hline Stock exchange listing & Independent samples Mann Whitney U Test & 0.454 \\
\hline Report type (integrated or not) & Independent samples Mann Whitney U Test & $0.007^{* * *}$ \\
\hline
\end{tabular}

Asymptotic significance is displayed. Note: ${ }^{*}, * *$, and ${ }^{* * *}$ denote statistical significance at $10 \%, 5 \%$, and $1 \%$ levels, respectively.

The analysis highlights the following findings.

1. "Home country" factor and 22 groups of banks (one group per country) have been examined. At the level of significance of $5 \%$, the country is a discriminatory factor in the contribution of banks to the SDGs. The null hypothesis ( $p$-value $<0.05$ ) is rejected: It can be affirmed that the country may differentiate the contribution to the SDGs. Consistently with Jensen and Berg [70] and Vormedal [71], specific attributes of the country of origin are relevant determinants for reporting. The relevance of a link between country and orientation toward the SDGs is confirmed by recent papers, which stress the importance of studies based on a comparison between the policies implemented by each country in pursuing the 17 goals [72]. This result also corroborates the findings obtained from the study by Ike et al. [20], which shows that the influence of the Country System in the reporting on the SDGs also impacts on the prioritization of goals.

2. The "legal system" factor and two groups have been examined: The civil law system and common law system. At the level of significance of $5 \%$, the legal system is a discriminatory factor in the contribution of banks to the SDGs. The null hypothesis ( $p$-value $<0.01)$ is rejected; in the two groups of civil law and common law a significant statistical difference exists between the distributions of scores. The result could confirm the findings found by other studies, which, comparing sustainability disclosure between companies in civil law and common law countries, show the presence of significant statistical differences [73-76]. 
3. The "Business model" factor and seven groups of banks (one group per each business model) have been examined. Table 2 indicates that, at the level of significance of $5 \%$, the difference between various bank models shall not be considered discriminatory of the contribution toward the SDGs.

4. The "Stock exchange listing" factor and two groups of banks have been examined. The tests indicate that the listing of banks does not seem to represent a discriminatory factor in the orientation toward the SDGs. Consistent with signaling theory and previous literature [77-79] on the role of listed firms in driving change, we expected listed banks to have a much broader approach to SDGs than unlisted banks. The results do not confirm expectations.

5. The "Integrated report" factor and two groups of banks have been examined. Table 2 shows that, at the level of significance of $5 \%$, the null hypothesis ( $p$-value $<0.01)$ is rejected: The choice to draw up an integrated report is a discriminatory factor in the contribution to the SDGs. This result is consistent with the findings of the study by Rosati and Faria [3], in which the compliance with a sustainability framework represents an internal discriminatory factor in terms of SDGs reporting.

Essentially, it could be said that, according to the non-parametric tests conducted, the factors that seem to differentiate banks in terms of contribution to the SDGs are:

1 Country of origin;

2 Legal system;

3 Adoption of an integrated report;

The business model and listing, conversely, do not seem to represent discriminatory factor in the contribution of banks toward the SDGs.

\section{Conclusions}

The results of this paper contribute to enriching the scientific debate within the issue of the relationship between the European financial sector and sustainable development for two main reasons. The first reason is that the study provides an analysis of the reporting on the SDGs in the banking sector of the $22 \mathrm{EU}$ countries, which, as well known, have started an empowerment process toward the non-financial reporting. The last years have been interested by the introduction of several policies on sustainability such as the Directive 95/2014/EU and the European New Green Deal [80]. However, an increasing number of scholars have started to discuss about the criticisms related to a "one-size-fits-all" approach toward sustainable practices [81]. Our results confirm this evidence. In particular, despite the presence of a common market, the analysis reveals that the orientation toward the SDGs is different between the Member States. The second reason consists of having identified some factors that seem to discriminate the contribution of EU Countries' banks to the SDGs.

The results of this study are consistent with essentially two types of analysis, namely a statistical-descriptive analysis and a statistical-inferential analysis.

By referring to the results of the first type of analysis, the paper shows the following aspects:

1. The priority SDGs in EU banks, similarly to other international surveys [12,13], are: Goals 8 (decent work and economic growth) and 13 (fight against climate change), namely high-impact goals for the banking business.

2. There is a substantial uniformity in the prioritization of the SDGs within EU countries and types of bank, also confirmed by a comparison between listed and non-listed banks.

3. The "scope" of contribution to SDGs from the European banks is narrow. It is higher in emerging countries such as Estonia, Croatia, and Poland with significant differences in comparing banks operating in the same country.

More generally, the results seem to confirm a poor propensity of EU banks to report on issues linked to sustainable development. The mandatory disclosure within the financial area appears to impact rather ineffectively on the voluntary disclosure with regard to the SDGs. 
Inferential statistical results confirm this hypothesis and show how bank business model and listing do not represent factors able to impact on the bank contribution to the SDGs. The integrated report, conversely, seems a more strategic driver able to boost a disclosure more addressed to the goals of sustainable development.

With regard to external factors, the paper shows results that are consistent with the findings of other studies, highlighting that the legal system can contribute to differentiate SDG reports. Furthermore, despite the presence of a single Communitarian Legislator, which should reduce the differences and bring together different orientations, the country seems to represent a discriminating factor against SDG reporting.

To conclude, although a solid orientation of banks toward sustainable development does not seem to arise from the SDG reporting, it may also be affirmed that further interventions from EU authorities in terms of investment and funding activities toward the goals of sustainable development and the obligation to report on the results achieved will probably determine, in the short term, an appreciable development in this direction.

The theoretical implications of our research are represented by the development of new knowledge on SDG reporting. Understanding the contribution provided by accountability practices on SDGs represents one of the main challenges for scholars [22,23]. Investigating the dynamics that impact on banks' approach to sustainable development is a central point within the debate due to the lack of scientific contribution on the topic [31,32]. The results of the research contribute to highlighting the type and the level of the commitment of the banks in the path towards the SDGs, emphasizing that the wide freedom that States enjoy, the lack of strong institutional arrangements, and the non-binding nature of the goals make the strategic orientation towards SDGs more cumbersome and slow. Furthermore, this study contributes to the research on SDGs by highlighting the roles of integrated reporting for the achievement of the Sustainable Development Agenda.

From a managerial point of view, it supports a better understanding and identification of the vulnerabilities in the SDG reporting and enables managers to assess the contribution to the SDGs against the competitors in the same country and in a wider context in easy and fast way.

From the policy point of view, the study contribute to understanding some characteristics that are related to the bank commitment to engage in SDG reporting and can be useful for policymakers responsible for the development of country-specific policies to identify the directions to promote sustainability orientation and support banks in contributing to the SDGs.

This paper is a first attempt to monitor the status of SDG reporting in the banking sector focusing on GRI and non-GRI reporting organizations and shall be repeated over time. It may also be extended to a range of communication and engagement instruments such as social media.

However, it also shows its limits: The bank contribution to the SDGs is linked to a disclosure investigation of sustainability reports and the study does not make an evaluation of the SDGs effectively reached.

The investigation of both internal and external discriminatory factors is respectively limited to bank listing/business model/preparation of an integrated report and country/legal system and does not include other factors such as company size considered relevant by other studies.

A more detailed analysis of the sector and country of origin might highlight additional discriminatory factors related to SDG reporting. Future studies might focus on individual attributes (attitudes, beliefs, commitment) of governance members to engage with and report on the SDGs. Furthermore, future research might test the results of the study in the light of the new version (March 2020) of the document [82] considered for disclosure analysis. According to Allen and colleagues [83], regular reviews of national progress and approaches to implementing the SDGs are desirable to ensure that emerging knowledge is effectively advising national practice.

A final consideration regards the effects that the COVID-19 pandemic will have on the banks' orientation towards the SDGs. The increasing awareness and concern for the impacts of non-financial risks could accentuate attention and act as a driving force for actions aimed at achieving all or 
some SDGs. From another point of view, the slowdown of all the activities and firm crisis could increase nonperforming loans and the possibility in extreme cases of bank runs and slow down the investments destined for the achievement of the SDGs and the improvement of the SDG reporting. Therefore, the analysis of the impact of COVID-19 on the contribution of banks to SDGs opens up new research perspectives.

Author Contributions: S.C. and A.V. developed the conceptualization, methodology and data analysis and wrote the original draft of the manuscript. P.S. and V.B. supervised and validated the research direction. All authors reviewed and edited the manuscript after peer review. All authors have read and agreed to the published version of the manuscript.

Funding: This research received no external funding.

Conflicts of Interest: The authors declare no conflict of interest.

\section{References}

1. Pillai, K.V.; Slutsky, P.; Wolf, K.; Duthler, G.; Stever, I. Companies' Accountability in Sustainability: A Comparative Analysis of SDGs in Five Countries. In Sustainable Development Goals in the Asian Context; Servaes, J., Ed.; Springer: Singapore, 2017; pp. 85-106. ISBN 978-981-10-2815-1.

2. Agarwal, N.; Gneiting, U.; Mhlanga, R. Raising the bar: Rethinking the role of business in the Sustainable Development Goals; Oxfam Discussion Papers; Oxfam: Boston, MA, USA, 2017; pp. 1-32. [CrossRef]

3. Rosati, F.; Faria, L.G.D. Business contribution to the Sustainable Development Agenda: Organizational factors related to early adoption of SDG reporting. Corp. Soc. Responsib. Environ. Manag. 2019, 26, 588-597. [CrossRef]

4. Task Force on Climate-Related Financial Disclosures. Recommendations of the Task Force on Climate-related Financial Disclosures i Letter from Michael R. Bloomberg; TFCD: Basel, Switzerland, 2017.

5. EU Commission. Directive 2014/95/eu of the European Parliament and of the Council-of 22 October 2014-Amending Directive 2013/34/EU as Regards Disclosure of Non-Financial and Diversity Information by Certain Large Undertakings and Groups; European Commission: Brussels, Belgium, 2014.

6. Storey, M.; Killian, S.; O'Regan, P. Responsible management education: Mapping the field in the context of the SDGs. Int. J. Manag. Educ. 2017, 15, 93-103. [CrossRef]

7. Leadership Council of the Sustainable Development Solutions Network. Indicators and a Monitoring Framework for the Sustainable Development Goals. Launching a Data Revolution for the SDGs; SDSN: Paris, France, 2015; p. 160.

8. United Nations Global Compact. United Nations Global Compact Progress Report: Business Solutions to Sustainable Development; UN Global Compact: New York, NY, USA, 2017; p. 99.

9. World Bank. The Word Bank-Annual Report; World Bank: Washington, DC, USA, 2017; p. 80.

10. Deloitte-SDA Bocconi. Osservatorio Nazionale sulla Rendicontazione non Finanziaria ex D. Lgs. 254/2016; Report; Deloitte: Milan, Italy, 2018; pp. 1-40.

11. United States Council for International Business. Leveraging the Business Sector for a Sustainable Future. Achieving the UN Sustainable Development Goals through Corporate Sustainability; USCIB: New York, NY, USA, 2018.

12. Klynveld Peat Marwick Goerdeler. How to Report on the SDGs What Good Looks Like and Why it Matters; KPMG International: Amstelveen, The Netherlands, 2018.

13. PricewaterhouseCoopers. SDG Reporting Challenge 2017: Exploring Business Communication on the Global Goals; Annual Report; PwC: London, UK, 2017; 40p.

14. Klynveld Peat Marwick Goerdeler. The Road Ahead: KPMG International Survey of Corporate Responsibility Reporting; KPMG International: Amstelveen, The Netherlands, 2017; Volume 8, pp. 792-793.

15. Gruppo di Studio per il Bilancio Sociale. The SDGs in the Reports of the Italian Companies; Franco Angeli: Milan, Italy, 2019; p. 156. ISBN 9788891797537.

16. Donald, K.; Way, S. Accountability for the Sustainable Development Goals: A Lost Opportunity? Ethics \& International Affairs: New York, NY, USA, 2015; pp. 201-213.

17. World Business Council for Sustainable Development. Striking the Balance Sustainable Development Reporting; WBCS: Geneva, Switzerland, 2002. 
18. Weitz, N.; Carlsen, H.; Nilsson, M.; Skånberg, K. Towards systemic and contextual priority setting for implementing the 2030 agenda. Sustain. Sci. 2018, 13, 531-548. [CrossRef] [PubMed]

19. Van Zanten, J.A.; van Tulder, R. Multinational enterprises and the Sustainable Development Goals: An institutional approach to corporate engagement. J. Int. Bus. Policy 2018, 1, 208-233. [CrossRef]

20. Ike, M.; Donovan, J.D.; Topple, C.; Masli, E.K. The process of selecting and prioritising corporate sustainability issues: Insights for achieving the Sustainable Development Goals. J. Clean. Prod. 2019, 236. [CrossRef]

21. Chapman, A.; Shigetomi, Y. Developing national frameworks for inclusive sustainable development incorporating lifestyle factor importance. J. Clean. Prod. 2018, 200, 39-47. [CrossRef]

22. Guthrie, J.; Parker, L.D.; Dumay, J.; Milne, M.J. What counts for quality in interdisciplinary accounting research in the next decade: A critical review and reflection. Account. Audit. Account. J. 2019, 32, 2-25. [CrossRef]

23. Bebbington, J.; Unerman, J. Achieving the United Nations Sustainable Development Goals: An enabling role for accounting research. Account. Audit. Account. J. 2018, 31, 2-24. [CrossRef]

24. Schaltegger, S. Linking Environmental Management Accounting: A Reflection on (Missing) Links to Sustainability and Planetary Boundaries. Soc. Environ. Account. J. 2018, 38, 19-29. [CrossRef]

25. Pizzi, S.; Venturelli, A.; Caputo, F. The "comply-or-explain" principle in directive 95/2014/EU. A rhetorical analysis of Italian PIEs. Sustain. Account. Manag. Policy J. 2020. ahead of print. [CrossRef]

26. Sachs, J.D. From millennium development goals to sustainable development goals. Lancet 2012, 379, 2206-2211. [CrossRef]

27. Dumay, J.; Frost, G.; Beck, C. Material legitimacy: Blending organisational and stakeholder concerns through non-financial information disclosures. J. Account. Organ. Change 2015, 11, 2-23. [CrossRef]

28. Deegan, C. Introduction: The legitimising effect of social and environmental disclosures-A theoretical foundation. Account. Audit. Account. J. 2002, 15, 282-311. [CrossRef]

29. García-Sánchez, I.M.; Aibar-Guzmán, B.; Aibar-Guzmán, C.; Rodríguez-Ariza, L. "Sell” recommendations by analysts in response to business communication strategies concerning the Sustainable Development Goals and the SDG compass. J. Clean. Prod. 2020, 255, 120194. [CrossRef]

30. Buhmann, K. Future perspectives: Doing good but avoiding SDG-washing Creating relevant societal value without causing harm. In OECD Guidelines for Multinational Enterprises: A Glass Half Full; OECD: Paris, France, 2013; pp. 127-135.

31. Tsalis, T.A.; Malamateniou, K.E.; Koulouriotis, D.; Nikolaou, I.E. New challenges for corporate sustainability reporting: United Nations' 2030 Agenda for sustainable development and the sustainable development goals. Corp. Soc. Responsib. Environ. Manag. 2020, 27, 1617-1629. [CrossRef]

32. Avrampou, A.; Skouloudis, A.; Iliopoulos, G.; Khan, N. Advancing the Sustainable Development Goals: Evidence from leading European banks. Sustain. Dev. 2019, 27, 743-757. [CrossRef]

33. Bonifácio Neto, J.; Branco, M.C. Controversial sectors in banks' sustainability reporting. Int. J. Sustain. Dev. World Ecol. 2019, 26, 495-505. [CrossRef]

34. Kumar, P.; Ahmed, F.; Singh, R.K.; Sinha, P. Determination of hierarchical relationships among sustainable development goals using interpretive structural modeling. Environ. Dev. Sustain. 2018, 20, 2119-2137. [CrossRef]

35. Unerman, J.; Chapman, C. Academic Contributions to Enhancing Accounting for Sustainable Development. Account. Organ. Soc. 2014, 39, 385-394. [CrossRef]

36. Ferguson, J.; Power, D.; Stevenson, L.; Collison, D. Shareholder protection, income inequality and social health: A proposed research agenda. Account. Forum 2017, 41, 253-265. [CrossRef]

37. Annan-Diab, F.; Molinari, C. Interdisciplinarity: Practical approach to advancing education for sustainability and for the Sustainable Development Goals. Int. J. Manag. Educ. 2017, 15, 73-83. [CrossRef]

38. Gray, R. Is accounting for sustainability actually accounting for sustainability ... and how would we know? An exploration of narratives of organisations and the planet. Account. Organ. Soc. 2010, 35, 47-62. [CrossRef]

39. Moneva, J.M.; Archel, P.; Correa, C. GRI and the camouflaging of corporate unsustainability. Account. Forum 2006, 30, 121-137. [CrossRef]

40. Diouf, D.; Boiral, O. The quality of sustainability reports and impression management: A stakeholder perspective. Account. Audit. Account. J. 2017, 30, 643-667. [CrossRef]

41. Watson, A.; Shrives, P.; Marston, C. Voluntary disclosure of accounting ratios in the UK. Br. Account. Rev. 2002, 34, 289-313. [CrossRef] 
42. Le Blanc, D. Towards Integration at Last? The Sustainable Development Goals as a Network of Targets. Sustain. Dev. 2015, 23, 176-187. [CrossRef]

43. Moggi, S.; Bonomi, S.; Ricciardi, F. Against food waste: CSR for the social and environmental impact through a network-based organizational model. Sustainability 2018, 10. [CrossRef]

44. Griggs, D.; Nilsson, M.; Stevance, A.; McCollum, D. A Guide To SDG Interactions: From Science; International Council for Science: Paris, France, 2017; pp. 1-239. [CrossRef]

45. Hajer, M.; Nilsson, M.; Raworth, K.; Bakker, P.; Berkhout, F.; de Boer, Y.; Rockström, J.; Ludwig, K.; Kok, M. Beyond cockpit-ism: Four insights to enhance the transformative potential of the sustainable development goals. Sustainability 2015, 7, 1651-1660. [CrossRef]

46. Gunawan, J.; Permatasari, P.; Tilt, C. Sustainable development goal disclosures: Do they support responsible consumption and production? J. Clean. Prod. 2020, 246, 118989. [CrossRef]

47. Rosati, F.; Faria, L.G.D. Addressing the SDGs in sustainability reports: The relationship with institutional factors. J. Clean. Prod. 2019, 215, 1312-1326. [CrossRef]

48. Izzo, M.F.; Ciaburri, M.; Tiscini, R. The challenge of sustainable development goal reporting: The first evidence from italian listed companies. Sustainability 2020, 12. [CrossRef]

49. Kourula, A.; Pisani, N.; Kolk, A. Corporate sustainability and inclusive development: Highlights from international business and management research. Curr. Opin. Environ. Sustain. 2017, 24, 14-18. [CrossRef]

50. Ranängen, H.; Cöster, M.; Isaksson, R.; Garvare, R. From global goals and planetary boundaries to public governance-A framework for prioritizing organizational sustainability activities. Sustainability 2018, 10. [CrossRef]

51. Ernst \& Young. How Do You Fund a Sustainable Tomorrow? EY: London, UK, 2017.

52. Mhlanga, R.; Gneiting, U.; Agarwal, N. Walking the Talk; Oxfam Discussion Papers; Oxfam: Boston, MA, USA, 2018. [CrossRef]

53. Hák, T.; Janoušková, S.; Moldan, B. Sustainable Development Goals: A need for relevant indicators. Ecol. Indic. 2016, 60, 565-573. [CrossRef]

54. Hahn, R.; Kühnen, M. Determinants of sustainability reporting: A review of results, trends, theory, and opportunities in an expanding field of research. J. Clean. Prod. 2013, 59, 5-21. [CrossRef]

55. Lozano, R. A holistic perspective on corporate sustainability drivers. Corp. Soc. Responsib. Environ. Manag. 2015, 22, 32-44. [CrossRef]

56. Adams, C.A. The Sustainable Development Goals, Integrated Thinking and the Integrated Report; IIRC and ICAS: London, UK, 2017; ISBN 978-1-909883-41-3.

57. Biermann, F.; Kanie, N.; Kim, R.E. Global governance by goal-setting: The novel approach of the UN Sustainable Development Goals. Curr. Opin. Environ. Sustain. 2017, 26-27, 26-31. [CrossRef]

58. European Commission. Guidelines on Reporting Climate-Related Information; European Commission: Brussels, Belgium, 2019; 44p.

59. Consob. Documento di Consultazione 21 Luglio 2017-Disposizioni Attuative del decreto legislativo 30 Dicembre 2016, n.254 Relativo Alla Comunicazione di Informazioni di Carattere non Finanziario; Consob: Rome, Italy, 2017; pp. 3-4.

60. Global Reporting Initiative; CSR Europe. Member State Implementation of Directive 2014/95/EU: A comprehensive overview of how Member States are implementing the EU Directive on Non-financial and Diversity Information; CSR Europe and GRI: Brussels, Belgium, 2017; p. 10.

61. Krippendorff, K. Content Analysis, 4th ed.; SAGE: Thousand Oaks, CA, USA, 2018.

62. GRI; UN Global Compact; WBSCD. Linking the SDGs and GRI; Global Reporting Initiative: Amsterdam, The Netherlands, 2017.

63. Beattie, V.; McInnes, B.; Fearnley, S. A methodology for analysing and evaluating narratives in annual reports: A comprehensive descriptive profile and metrics for disclosure quality attributes. Account. Forum 2004, 28, 205-236. [CrossRef]

64. Beck, A.C.; Campbell, D.; Shrives, P.J. Content analysis in environmental reporting research: Enrichment and rehearsal of the method in a British-German context. Br. Account. Rev. 2010, 42, 207-222. [CrossRef]

65. Helfaya, A.; Whittington, M. Does designing environmental sustainability disclosure quality measures make a difference? Bus. Strateg. Environ. 2019, 28, 525-541. [CrossRef]

66. Leopizzi, R.; Iazzi, A.; Venturelli, A.; Principale, S. Nonfinancial risk disclosure: The "state of the art" of Italian companies. Corp. Soc. Responsib. Environ. Manag. 2020, 27, 358-368. [CrossRef] 
67. Sheldon, M.D.; Jenkins, J.G. The influence of firm performance and (level of) assurance on the believability of management's environmental report. Account. Audit. Account. J. 2020. ahead of print. [CrossRef]

68. Okafor, O.N.; Adebisi, F.A.; Opara, M.; Okafor, C.B. Deployment of whistleblowing as an accountability mechanism to curb corruption and fraud in a developing democracy. Account. Audit. Account. J. 2020. [CrossRef]

69. Eurostat; European Commission. Sustainable Development in the European Union-Monitoring Report On Progress Towards the Sdgs in An Eu Context; European Commission: Brussels, Belgium, 2018; Volume 2001, ISBN 9789279887451.

70. Jensen, J.C.; Berg, N. Determinants of Traditional Sustainability Reporting Versus Integrated Reporting. An Institutionalist Approach. Bus. Strateg. Environ. 2012, 21, 299-316. [CrossRef]

71. Vormedal, I.H.; Ruud, A. Sustainability reporting in Norway-An assessment of performance in the context of legal demands and socio-political drivers. Bus. Strateg. Environ. 2009, 18, 207-222. [CrossRef]

72. Gusmão Caiado, R.G.; Leal Filho, W.; Quelhas, O.L.G.; de Mattos Nascimento, D.L.; Ávila, L.V. A literature-based review on potentials and constraints in the implementation of the sustainable development goals. J. Clean. Prod. 2018, 198, 1276-1288. [CrossRef]

73. Webb, K.A.; Cahan, S.F.; Sun, J. The effect of globalization and legal environment on voluntary disclosure. Int. J. Account. 2008, 43, 219-245. [CrossRef]

74. Frías-Aceituno, J.V.; Rodríguez-Ariza, L.; García-Sánchez, I.M. Is integrated reporting determined by a country's legal system? An exploratory study. J. Clean. Prod. 2013, 44, 45-55. [CrossRef]

75. Mio, C.; Venturelli, A. Non-financial Information About Sustainable Development and Environmental Policy in the Annual Reports of Listed Companies: Evidence from Italy and the UK. Corp. Soc. Responsib. Environ. Manag. 2013, 20, 340-358. [CrossRef]

76. Venturelli, A.; Caputo, F.; Leopizzi, R.; Pizzi, S. The state of art of corporate social disclosure before the introduction of non-financial reporting directive: A cross country analysis. Soc. Responsib. J. 2019, 15, 409-423. [CrossRef]

77. Yang, X.; Wang, Y.; Hu, D.; Gao, Y. How industry peers improve your sustainable development? The role of listed firms in environmental strategies. Bus. Strateg. Environ. 2018, 27, 1313-1333. [CrossRef]

78. Zeng, S.X.; Xu, X.D.; Yin, H.T.; Tam, C.M. Factors that Drive Chinese Listed Companies in Voluntary Disclosure of Environmental Information. J. Bus. Ethics 2012, 109, 309-321. [CrossRef]

79. Chang, L.; Li, W.; Lu, X. Government engagement, environmental policy, and environmental performance: Evidence from the most polluting chinese listed firms. Bus. Strateg. Environ. 2015, 24, 1-19. [CrossRef]

80. European Commission. The European Green Deal; European Commission: Brussels, Belgium, 2019; Volume 53.

81. La Torre, M.; Sabelfeld, S.; Blomkvist, M.; Tarquinio, L.; Dumay, J. Harmonising non-financial reporting regulation in Europe: Practical forces and projections for future research. Meditari Account. Res. 2018, 26, 598-621. [CrossRef]

82. Global Reporting Initiative. Linking the SDGs and the GRI Standards; Global Reporting Initiative: Amsterdam, The Netherlands, 2020.

83. Allen, C.; Metternicht, G.; Wiedmann, T. Initial progress in implementing the Sustainable Development Goals (SDGs): A review of evidence from countries. Sustain. Sci. 2018, 13, 1453-1467. [CrossRef]

(C) 2020 by the authors. Licensee MDPI, Basel, Switzerland. This article is an open access article distributed under the terms and conditions of the Creative Commons Attribution (CC BY) license (http://creativecommons.org/licenses/by/4.0/). 